\title{
The genes of cell death and cellular susceptibility to apoptosis in the ovary: a hypothesis
}

\author{
Jonathan L. Tilly ${ }^{1,2}$, and Kim I. Tilly ${ }^{1}$ and Gloria I. Perez ${ }^{1}$ \\ ${ }^{1}$ Department of Obstetrics, Gynecology and Reproductive Biology, Harvard \\ Medical School, and the Vincent Center for Reproductive Biology, \\ Massachusetts General Hospital, VBK137E-GYN, 55 Fruit Street, Boston, MA \\ 02114 USA \\ 2 corresponding author: tel: 617-724-2182; fax: 617-726-7548; email: \\ tilly.jonathan@mgh.harvard.edu
}

Received 3.9.96; revised 12.12.96; accepted 16.12.96

Edited by M. Piacentini

\begin{abstract}
Recent advances in the field of cell death, primarily derived from gene-transfer experiments and manipulation of tumor cell lines in vitro, have identified key genes responsible for determining whether or not a given cell will initiate apoptosis. However, comparatively less is known of the role that the products of these genes play in physiological settings of cell death. In the ovary, a tremendous level of normal cell death takes place in the germline throughout the later stages of fetal development. This process is responsible for setting the absolute number of oocytes ('eggs') available for subsequent development and ovulation during adult life. Interestingly, death remains the fate of the vast majority of oocytes that survive the waves of attrition during fetal life and are endowed in the post-natal ovary as primordial follicles. This pool of oocytes is lost indirectly as a consequence of the death of the somatic (granulosa) cells that, in the case of a small percentage of the total follicles, support and nourish the oocyte until its release at ovulation. Due to the magnitude of cell death that occurs normally within the female gonad during both fetal development and post-natal life, the ovary has proven to be an excellent model to study the role of cell death genes in a physiological setting of endocrine-regulated apoptosis.
\end{abstract}

It is now known that a diverse spectrum of pro- and antiapoptosis susceptibility genes, including members of the bcl2 and CASP (ced-3/lce) gene families, are expressed in germ cells and/or somatic cells of the ovary. Many, but not all, of these genes are regulated by specific survival factors, such as gonadotropins and growth factors, and changes in the temporal patterns of cell death gene expression suggest an intimate association exists between the products of these genes and activation of cellular suicide. Moreover, pathological oocyte destruction, such as that triggered by exposure of female germ cells to chemotherapeutic compounds or environmental toxicants, may also be dependent upon genedriven apoptosis. As such, this review will discuss data supporting the hypothesis that the susceptibility of ovarian cells to death induction is dependent upon the pattern of cell death gene expression occurring within those cells prior to and/or concomitant with receipt of the stimulus for apoptosis. Elucidation of the relationship between germ cell loss and cell death genes may allow future intervention into the process of oocyte depletion associated with normal and pathophysiological reproductive senescence.

Keywords: apoptosis, Bcl-2, Bax, Bcl-x, p53, ICE, caspase, oocyte, granulosa cell, atresia

Abbreviations: Bax, Bcl-2-associated x-protein; Bcl-2, B-cell lymphoma/leukemia-2 protein; $\mathrm{Bcl}-\mathrm{x}$, $\mathrm{Bcl}-2$-related protein- $\mathrm{x}$; caspase, cysteine aspartic acid-specific protease; $\mathrm{FSH}$, folliclestimulating hormone; ICE, interleukin- $1 \beta$-converting enzyme; $\mathrm{LH}$, luteinizing hormone; SCF, stem cell growth factor (also referred to as Stee/ factor or kit-ligand).

\section{Apoptosis in the ovary: a brief historical account}

Numerous studies have now established that physiological cell death plays a fundamental role in the endowment of the primordial follicle stockpile during the peri-natal period and the subsequent depletion of the follicle pool by the degenerative process of atresia throughout prepubertal and reproductive life. The earliest known report of apoptosis in the ovary was made by Flemming in 1885 in a meticulously documented morphological study of how inner epithelial (granulosa) cells of rabbit ovarian follicles degenerate in vivo. The process of 'chromatolysis' was proposed as an underlying feature of this phenomenon, and in retrospective analysis the morphological characteristics described by Flemming (1885) perfectly match the criteria set forth by Kerr et al (1972) 87 years later for the identification of apoptotic cells. Despite this significant series of observations made over a century ago, the relationship between apoptosis and ovarian function essentially remained dormant, with the exception of several scattered morphological descriptions of cell turnover in the ovary (see, for example: Quatacker, 1971; Kerr et al, 1972; Byskov, 1974; Hirshfield and Midgley, 1978a; O'Shea et al, 1978; Braw et al, 1981), until the early part of this decade.

In light of the now well-known association between internucleosomal DNA fragmentation and apoptosis (Williams et al, 1974; Wyllie, 1980; Arends et al, 1990; Schwartzman and Cidlowski, 1993; Tilly, 1994), Zeleznik and co-workers (1989) identified the presence of a cationdependent endonuclease activity in rat ovarian granulosa and luteal cell nuclei capable of eliciting such a pattern of DNA cleavage. Furthermore, the presence of this endonucleolytic activity appeared to be endocrine-regulated, suggesting that the demise of granulosa cells during follicular atresia and of luteal cells during luteolysis, may 
be dependent upon acquisition of this enzyme during development of the respective tissues. This study was followed in 1991 by two reports linking apoptosis to the process of follicular atresia in three different vertebrate species in vivo (Hughes and Gorospe, 1991; Tilly et al, 1991), with both studies relying on the occurrence of oligonucleosome formation as an indicator of apoptotic death. With the interest in apoptosis and the ovary refueled by these investigations, the past several years have seen an exponential increase in the number of publications documenting the occurrence of apoptosis in granulosa cells during atresia in all animal species studied to date (reviewed in: Guthrie et al, 1995; Tilly, 1996; Tilly and Ratts, 1996). In addition, many studies utilizing cultured granulosa cells or intact follicles have identified important roles for a wide spectrum of endocrine, paracrine and autocrine factors, such as gonadotropins (Tilly et al, 1992, 1995a; Chun et al, 1994; Tilly and Tilly, 1995), growth factors (Tilly et al, 1992, 1995b; Chun et al, 1994; Luciano et al, 1994), and neuropeptides (Flaws et al, 1995a), in regulating granulosa cell apoptosis during the later stages of follicular development.

In contrast to the now generous supply of research data supporting a role for apoptosis in follicular atresia, comparatively little is known of the pathways responsible for attrition of oogonia and oocytes in the fetal and early post-natal ovary of vertebrate species (Beaumont and Mandl, 1961; Borum, 1961; Pinkerton et al, 1961; Baker, 1963; Forabosco et al, 1991). Recent flow cytometric analysis of germ cells isolated from fetal mouse gonads has demonstrated that apoptosis is at least one mechanism underlying prenatal oogonium and oocyte loss (Coucouvanis et al, 1993). These in vivo investigations have been supported by several in vitro studies documenting the occurrence of apoptosis by many criteria in primordial germ cells (Pesce et al, 1993; Pesce and De Felici, 1994) and oogonia/oocytes (Martimbeau et al, 1996) following deprivation of serum or cytokines needed for survival in culture. Based on the findings that the survival advantage conveyed by at least one of the cytokines tested in vitro, namely SCF (Dolci et al, 1991; Godin et al, 1991; Pesce et al, 1993; Martimbeau et al, 1996), is supported by in vivo assessments of defects in gametogenesis and fertility in mice lacking expression of functional SCF or SCF receptor (Mintz and Russell, 1957; Motro et al, 1991; Besmer et al, 1993), it is reasonable to assume that data derived from future analyses of apoptosis in these in vitro models of germ cell attrition will have significant physiological relevance.

\section{The bcl-2 : bax rheostat: a matter of life and death in the ovary?}

With the understanding that apoptosis is so critical to germ cell and granulosa cell fate came the second wave of investigations, that being identification of the intracellular effectors responsible for activating or repressing the order for cellular suicide in the ovary. The first set of genes evaluated in this context, as with most other paradigms of apoptosis, was $b c l-2$ and its family members (Reed, 1994; Korsmeyer, 1995).
Since the majority of available data pertaining to the ovary concern changes in $b c l-2$, bax and $b c l-x$ expression (see below), the following discussion will be limited to these three family members. Presently, it is believed that proteins encoded by members of the $b c /-2$ gene family interact via specific conserved domains (Yin et al, 1994) to form both homo- and heterodimers (Sato et al, 1994; Sedlak et al, 1995). Moreover, it has been proposed from manipulations of tumor cell lines that the relative ratio of the anti-apoptosis proteins, $\mathrm{Bcl}-2$ and $\mathrm{Bcl}-\mathrm{x}_{\mathrm{L}}$, to the pro-apoptosis factors, Bax and Bcl- $\mathrm{x}_{\mathrm{S}}$, in a given cell functions as a 'rheostat' to determine that cell's susceptibility to apoptosis following exposure to a deathpromoting stimulus (Boise et al, 1993; Oltvai et al, 1993; Oltvai and Korsmeyer, 1994). For example, transfection of certain cells with $b c l-2$ provides protection from such insults as tropic hormone deprivation, whereas gene-transfer of bax accelerates the rate at which these cells undergo apoptosis in response to the same stimulus (Oltvai et al, 1993; Reed, 1994; Korsmeyer, 1995). However, there is evidence that $\mathrm{Bcl}-2$ and $\mathrm{Bcl}-\mathrm{x}_{\mathrm{L}}$ may also act independent of each other and of Bax heterodimerization to promote cell survival (Cheng et al, 1996; Gottschalk et al, 1996), albeit these mechanisms remain illdefined and are beyond the scope of this review.

From the perspective of ovarian cell death, the presence and changes in expression of $b c l-2$, bax and $b c l-x$ in the ovary have been documented in several species (Rodger et al, 1995; Tilly et al, 1995a, 1996a,b; Johnson et al, 1996; Rueda et al, 1997). In the rodent ovary, the most studied model system for ovarian cell death research, Bax has emerged as the principal player in regulating both germ cell and granulosa cell demise. The first report along these lines evaluated the in vivo effects of gonadotropins on ovarian expression of $b c l-2$, bax and $b c l-x_{\mathrm{L} / \mathrm{S}}$ relative to the inhibition of granulosa cell death and follicular atresia, and further extended these observations by an analysis of these three genes in ovarian follicles deprived of tropic hormone support in vitro (Tilly et al, 1995a). The primary conclusion reached was that there exists a strong positive correlation between enhanced expression of bax, in the face of relatively constitutive $b c l-2$ and $b c l-x$ expression, and the induction of apoptosis in granulosa cells of follicles during atresia. This series of observations has been reinforced by a more recent analysis of ovaries collected from mice harboring a targeted disruption in the bax gene (Knudson et al, 1995). In accordance with the hypothesized role of Bax in granulosa cell apoptosis, follicles in Bax-deficient females contain granulosa cells that are apparently resistant to the induction of normal cell death during atresia (Knudson et al, 1995). These data, taken with recent preliminary observations that increased levels of Bax protein detected by immunohistochemistry in granulosa cells precede morphological evidence of follicle degeneration in the human ovary (Tilly et al, 1996b; manuscript submitted), collectively suggest that a rheostat mechanism involving a shift towards greater Bax levels is a critical step in the process of follicular atresia.

Interestingly, the fate of germ cells in the ovary during fetal development may also be driven by the status of the $\mathrm{Bcl}-2$ : Bax rheostat. Although there exists scant data describing expression of any $b c /-2$ gene family members 
in germ cells, morphologic and morphometric results derived from gene knock-out mice have proven quite informative. In the case of Bcl-2-deficient female mice, significantly fewer primordial follicles are endowed in the post-natal ovary as compared with follicular endowment in wild-type sister-littermates (Ratts et al, 1995). Since the number of follicles endowed can be used as an indicator of the degree of peri-natal germ cell loss, these data would argue that a shift in the rheostat to favor Bax (due to the absence of Bcl-2) in germ cells may lead to greater numbers of oogonia/oocytes lost during fetal development. By comparison, Bax-deficient female mice have a three-fold greater number of primordial follicles endowed in the ovary at 42 days of age post-partum (Knudson et al, 1996). These data would support the hypothesis that a shift in the rheostat away from Bax, possibly favoring greater $\mathrm{Bcl}-2$ (or $\mathrm{Bcl}-\mathrm{x}_{\mathrm{L}}$ ?) bioavailability, reduces death susceptibility in germ cells. Another potentially important implication of the results from the $b c /-2$ and bax gene knock-out experiments is that the Bcl-2:Bax rheostat can be shifted with dramatic consequences in the magnitude of cell death by altering the expression of only one of the genes. As such, future evaluations of $b c l-2$ family members in ovarian germ and somatic cells should consider that the absence of a change in expression one family member (such as $b c /-2$ or $b c l-x_{L}$ ) may still be important for setting the rheostat if expression of another opposing family member (such as bax) is altered.

Before closing this section, two additional points concerning the topic of $\mathrm{Bcl}-2$-related proteins and ovarian function require brief discussion. First, enhanced expression of bax has also been recently identified in other ovarian cell types during instances of apoptosis not related to germ cell attrition or follicular atresia (e.g. luteolysis; Tilly et al, 1996b; Rueda et al, 1997), further supporting a fundamental role for this specific death-susceptibility factor in multiple aspects of ovarian development and cyclic function. Second, activation of anti-oxidant defense pathways has been implicated as a primary survival mechanism for granulosa cells in developing follicles (Tilly and Tilly, 1995), consistent with the reported anti-apoptosis actions of $\mathrm{Bcl}-2$ being at least partly mediated via the effects of this protein on stabilizing the reduction-oxidation state of the cell and thus preventing apoptosis induced by accumulation of reactive oxygen species or their intermediates (Hockenberry et al, 1993; Kane et al, 1993; Steinman, 1995).

\section{The 553 tumor suppressor protein: a cytoplasmic link to the nucleus?}

The studies reviewed in the previous section establish that, in accordance with data derived from work with tumor cell lines and genetic manipulation, members of the $b c l-2$ gene family likely function as key participants determining the susceptibility of ovarian cells to a death stimulus. However, as with other cell systems, the mechanisms responsible for altering the Bcl-2: Bax rheostat in ovarian cells are currently unknown. The first glimpse into one potential signaling pathway comes from studies of the p53 protein. As a preface to these discussions, it is critical to first cite three recent investigations from Reed and colleagues (Miyashita et al, 1994a,b; Miyashita and Reed, 1995) that served as the impetus for evaluating the potential role of p53 in ovarian cell demise. These experiments, the first to establish an important link between p53 and transcriptional regulation of cell death genes, identified a p53-enhancer element in the bax gene promoter (Miyashita and Reed, 1995) and a p53-repressor element in the bcl-2 gene promoter (Miyashita et al, 1994a). Moreover, using a combination of in vivo and in vitro approaches, a positive correlation between p53 levels and bax expression, and a negative correlation between p53 levels and $b c l-2$ expression, in cells of various lineages was documented (Miyashita et al, 1994b). In the ovary, p53 protein has been localized by immunocytochemistry to the nuclei of granulosa cells destined for apoptosis during follicular atresia (Tilly et al, 1995c). Moreover, provision of exogenous gonadotropin support in vivo abolishes p53 immunoreactivity in the ovary (Tilly et al, 1995c), concomitant with a loss of bax expression (Tilly et al, 1995a) and a complete absence of apoptosis (Tilly et al, 1995a) in the same cell populations. These data, taken with evidence demonstrating p53-mediated apoptosis in granulosa cells by gene-transfer techniques (Keren-Tal et al, 1995), support the concept that ovarian survival factors may somehow prevent nuclear translocation of $\mathrm{p} 53$ as one means to shift the Bcl-2:Bax rheostat away from Bax predominance in granulosa cells.

Of final note in this section, there is recent evidence that the germ cell survival factor, SCF, can prevent p53-induced apoptosis in erythroleukemia cells (Abrahamson et al, 1995). Although the presence and function of p53 in female germ cells during the peri-natal waves of attrition is currently unknown, these findings suggest that one of the anti-apoptosis actions of SCF in the fetal ovary may be at the level of interfering with p53-mediated pathways of cell death induction in oogonia/oocytes. Collectively, the data discussed above underscore the importance of future work to continue to decipher the role of p53 in regulating apoptosis in germ cells and somatic cells of the ovary, studies that may be greatly facilitated with the current availability of p53-deficient mice.

\section{Caspases: the penultimate step to irrevocable cell death?}

For the sake of completeness, it is important to touch on the role of proteases, specifically those encoded by members of the CASP (Alnemri et al, 1996) or ced-3/lce gene family, in ovarian cell death. This concept is of particular interest in light of a recent report that caspases function downstream of Bcl-2like proteins in the regulation of cell death in vertebrates (Chinnaiyan et al, 1996), analogous to that described for the respective $\mathrm{Bcl}-2$ and caspase homologs in Caenorhabditis elegans, Ced-9 and Ced-3 (Hengartner and Horvitz, 1994). This proposed hierarchy between $\mathrm{Bcl}-2$ family members and caspases has recently been supported by two additional reports describing the ability of $\mathrm{Bcl}-2$ to prevent activation of caspase-3 (CPP32) in various paradigms of apoptosis (Estoppey et al, 1997; Perry et al, 1997). At this point, however, the mechanism(s) by which Bcl-2 acts in this regard remains to be established (Kumar, 1997). Nonetheless, 
members of the CASP gene family in vertebrates, of which there are now at least ten, are believed to function at a committal point(s) in cell death execution as the targets cleaved by these proteases are primarily homeostatic proteins found in both the cytoplasm and nucleus (Martin and Green, 1995; Fraser and Evan, 1996; Patel et al, 1996). To date, there exists only a single report of caspases in the ovary that demonstrated a reduction in expression of CASP-2 (Ich-1, the long isoform; Wang et al, 1994) and CASP-3 (CPP32; Fernandes-Alnemri et al, 1994) following in vivo gonadotropin stimulation of immature rats (Flaws et al, 1995b). However, in this same study, various inhibitors of serine and cysteine proteases did not alter the onset of apoptosis in granulosa cells of follicles incubated in vitro without hormonal support. The one exception was an inhibition of internucleosomal DNA fragmentation, but not morphological evidence of apoptosis, achieved with the putative cysteine protease inhibitor, sodium aurothiomalate (Flaws et al, 1995b).

Subsequent preliminary experiments with incubated follicles have now shown that sodium aurothiomalate is also a potent inhibitor of the nuclease(s) responsible for oligonucleosome formation in granulosa cells (Trbovich et al, 1996a). Thus, the discrepancy in the biochemical (absence of DNA ladders) versus morphological (presence of pyknosis, cellular condensation, budding) evidence can be attributed to the occurrence of high molecular DNA cleavage not prevented by this inhibitor in granulosa cells (Trbovich et al, 1996b). Although these data argue both for (expression and gonadotropin down-regulation of

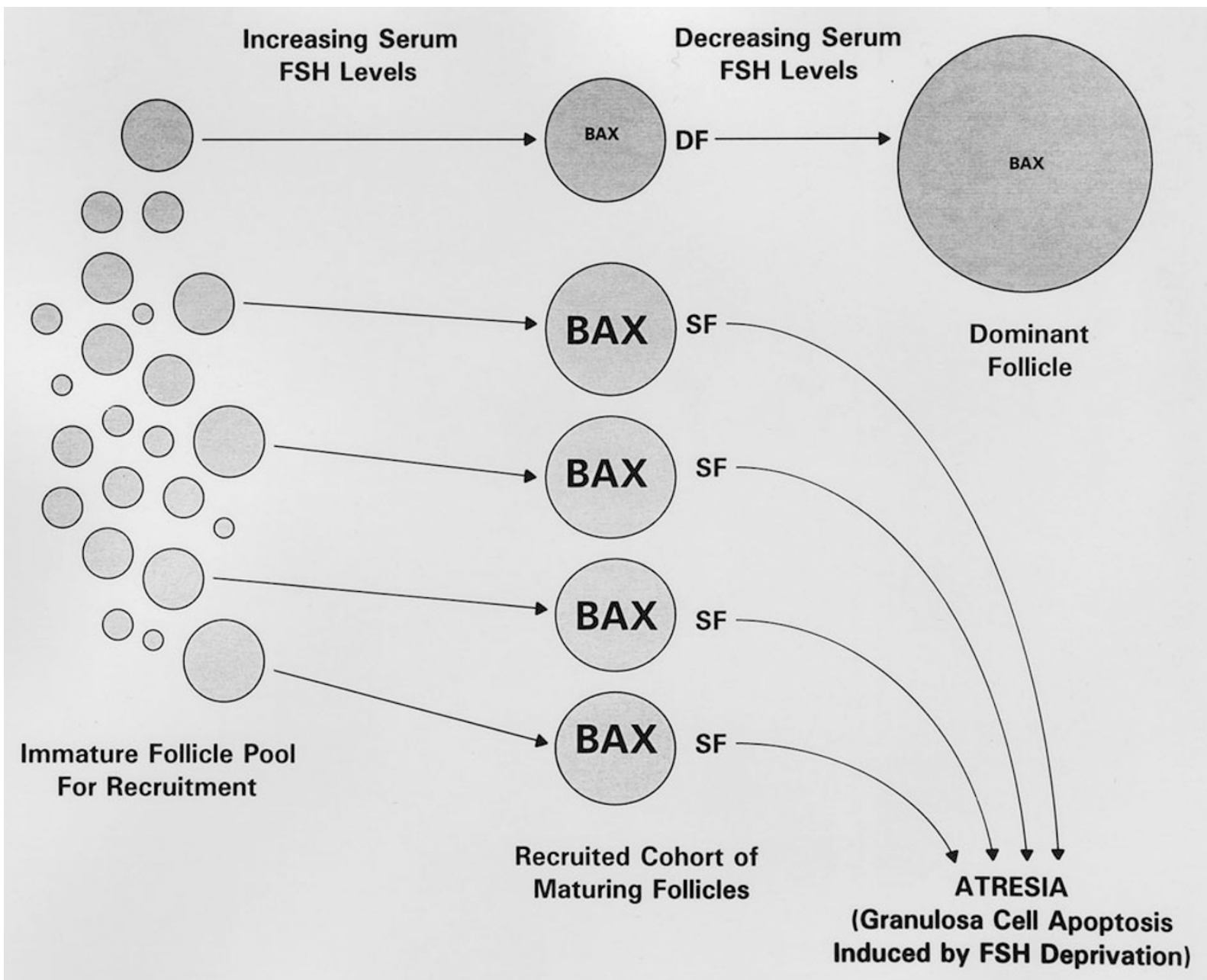

Figure 1 Hypothesized role of Bax in selection of the dominant follicle in the ovary of mono-ovulatory species. Each menstrual or estrous cycle, a cohort of follicles is recruited to begin the final steps of growth and maturation to the preovulatory stage of development. However, only one follicle will be selected as the dominant follicle (DF) for continued survival and ultimately ovulation, whereas the remaining subordinate follicles (SF) in the cohort undergo the degenerative process of atresia resulting from an induction of apoptosis in the follicular granulosa cells. From the data discussed in this review, it is hypothesized that granulosa cells within the different follicles possess varying levels of Bax protein, and that granulosa cells within the follicle that will be selected as dominant contain the lowest amounts of Bax (the amount of Bax is portrayed by the size of typography, with small letters indicating low Bax and large letters indicating high Bax). Upon declining FSH support, the likely trigger for atresia of the subordinate follicles, the granulosa cells possessing the lowest levels of Bax also exhibit the lowest susceptibility to tropic hormone (FSH) deprivation-induced apoptosis. As such, this feature may aid the dominant follicle in resisting activation of the atresia process, whereas the remaining follicles in the cohort initiate atresia due to a greater susceptibility of their granulosa cells to death induction, in the face of waning FSH levels. 


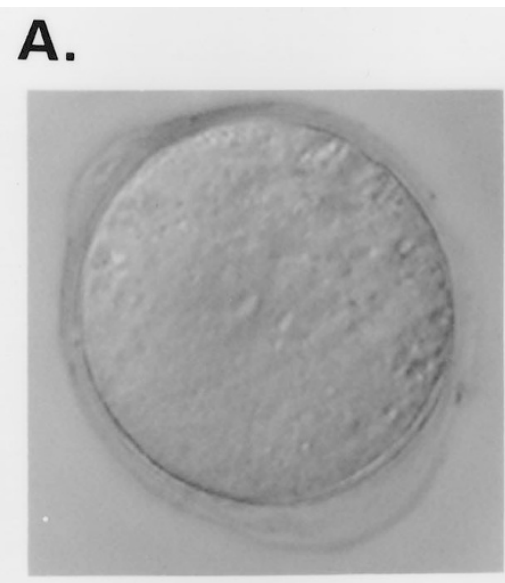

CONTROL OOCYTE

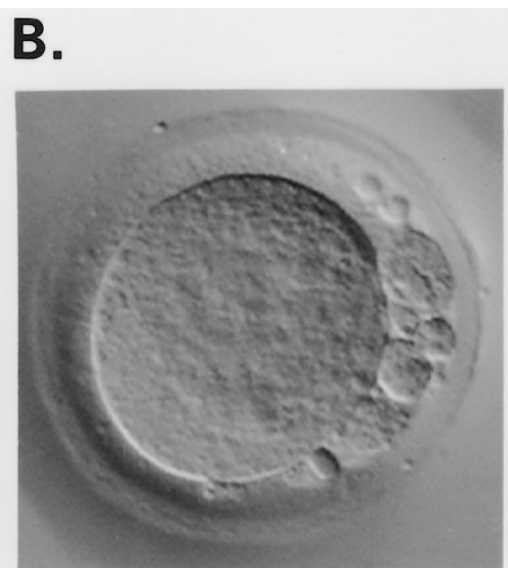

\section{OOCYTE EARLY IN THE APOPTOTIC PROCESS}

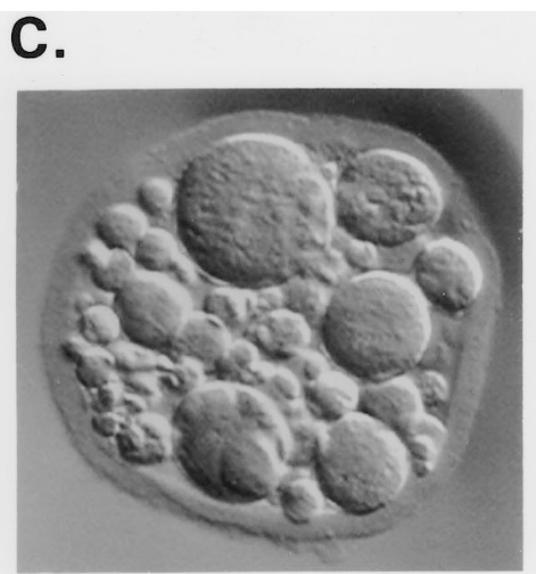

\section{OOCYTE LATE IN THE APOPTOTIC PROCESS}

Figure 2 Analysis of apoptosis in individual oocytes as a model to characterize events responsible for pathological conditions of ovarian germ cell depletion. (A) depicts a healthy single oocyte exposed to vehicle alone, whereas $(\mathbf{B})$ and $(\mathbf{C})$ show a progressive appearance of the apoptotic morphology in individual oocytes exposed to an ovotoxicant. Note the beginning of the budding phenomenon in the oocyte shown in (B), and the dramatic increase in the extent of membrane budding and cellular fragmentation of the oocyte depicted in (C).

caspases in the ovary) and against (lack of effect of general protease inhibitors on apoptosis in incubated follicles) the participation of proteases in ovarian cell death, more recent experiments using cell-permeable and specific peptide inhibitors of this class of proteases (zVADFMK and zDEVD-FMK) have further supported the concept that these gene products are in fact important for apoptosis in both ovarian granulosa cells (Maravei et al, 1996; manuscript submitted) and germ cells (G.I. Perez, C.M. Knudson, L. Leykin, G.A.J. Brown, S.J. Korsmeyer, J.L. Tilly, unpublished data). Conclusive proof of this hypothesis, however, may await the availability of data generated from the future in-depth analysis of ovarian germ cell and follicular dynamics in mice lacking expression of one or more of the caspases generated through gene-targeting approaches.

\section{Cell death genes in the ovary: what does it all mean?}

In summary, great strides have been made in understanding the pathways activated or repressed in ovarian cells that may alter their fate following local endocrine signaling events. For the most part, the data currently available in the literature support the concept that apoptosis in the ovary is dependent upon the expression of certain key cell death genes, such as bax, and that the susceptibility of any given cell to apoptosis is likely decided before receipt of the actual stimulus for death. The possible implications of these data are many, and the following scenario provides just one example. A problem faced by ovarian physiologists is understanding the basis of follicle selection, whereby in mono-ovulatory species (e.g. humans) one dominant follicle is selected from a cohort of follicles at a comparable developmental stage for continued survival, growth and ovulation (Hodgen, 1982; Ginther et al, 1996). Although it is known that the remaining follicles are lost by atresia, the reasons that one follicle possesses a 'survival' advantage over other follicles, some of which even lie proximal to the dominant follicle, remain to be fully elucidated. It is known that a loss of FSH support, achieved via negative feedback loops involving among other things increased estradiol and inhibin secretion from the ovary during dominant follicle selection (Zeleznik, 1981; Hodgen, 1982; Zeleznik et al, 1985; Ginther et al, 1996), is likely the fundamental event involved in triggering demise of the subordinate follicles. This argument is supported by data indicating that gonadotropins do in fact maintain a suppression of apoptosis in granulosa cells of antral follicles both in vivo and in vitro (Hirshfield and Midgley, 1978b; Braw et al, 1981; Tilly et al, 1992, 1995a; Chun et al, 1994; Tilly and Tilly, 1995). However, in theory all of the follicles in the developing cohort receive the same ovarian blood supply that carries this important survival factor from the pituitary gland (albeit differences in blood flow or vascularization on a per follicle basis may be an important variable; Zeleznik et al, 1981), and thus a switch from dependency on $\mathrm{FSH}$ to luteinizing hormone (LH), as reflected by increased acquisition of functional LH receptors in the granulosa cells in the dominant follicle, has been proposed as a basis for why the dominant follicle continues to grow and survive in the presence of declining FSH (Ginther et al, 1996).

However, based on the data reviewed above, an alternate hypothesis is offered. It is suggested that certain follicles, by virtue of the patterns of cell death genes expressed in their granulosa cells, possess a predetermined survival advantage in the face of waning $\mathrm{FSH}$ 
support. In the case of the Bcl-2:Bax rheostat, this concept is supported by evidence showing that expression of bax in granulosa cells precedes apoptosis and is inhibited by gonadotropins, and that the absence of functional Bax causes defects in the normal induction of granulosa cell death during atresia. Thus, it may be that the relative levels of Bax in granulosa cells of different follicles, all of which appear morphologically and developmentally similar, is an important factor in determining whether or not a given follicle will undergo atresia upon a decrease in the level of FSH support seen by all follicles in the later half of the follicular phase (Figure 1). A similar hypothesis could be proposed for the massive attrition of germ cells in the developing ovary during the peri-natal period, with SCF substituting for $\mathrm{FSH}$ as the primary survival signal present in limited quantities. In this case, the status of the Bcl2 : Bax rheostat in any given germ cell may be a primary determinant of which oogonia/oocytes live and which oogonia/oocytes die in the presence of suboptimal levels of SCF derived from the surrounding somatic cells.

Regardless of the outcome of future experiments to test the validity of these hypotheses, it remains that the concepts of apoptosis and cell death genes, as they pertain to ovarian function, are intriguing and are here to stay. The use of knowledge gained by these investigations has already permitted recent breakthroughs in understanding pathological conditions of germ cell loss. For example, it has been reported that oocyte loss following exposure of the ovary to environmental toxicants occurs via an induction of apoptosis (Mattison, 1980; Springer et al, 1996a) and this process is preceeded by increased expression of bax in those follicles or oocytes destined for destruction (Springer et al, 1996b; G.I. Perez, X.-J. Tao and J.L. Tilly, unpublished data). Furthermore, using an in vitro culture system to analyze apoptosis in individual oocytes under defined conditions (Figure 2), we have recently observed that oocytes collected from Bax-deficient female mice are resistant to apoptosis induced by exposure to a variety of ovotoxicants (G.I. Perez, C.M. Knudson, L. Leykin, G.A.J. Brown, S.J. Korsmeyer and J.L. Tilly, unpublished data). As such, data derived from future studies of apoptosis and cell death genes in the ovary will likely continue to open new avenues for research in reproductive physiology, as well as to provide a unique model for assessing the function of known, and as yet unknown, cell death regulatory factors in a physiologically-relevant setting of fetal and post-natal cell death.

\section{Acknowledgements}

We would like to thank Professor Massimo De Felici (Universita di Roma 'Tor Vergata', Rome, Italy) for his efforts in the organization of this series of parallel reviews, and we are indebted to Drs. Stanley J. Korsmeyer and C. Michael Knudson (Washington University School of Medicine, St. Louis, MO, USA) for invaluable collaborative interactions. The studies conducted by the authors and described herein were supported by public health service grants from the National Institutes of Health of the United States (R01-HD34226, R01-AG12279, R01-ES06999, R55-HD31188, Office of Research on Women's Health), by a grant from the American
Federation for Aging Research, and by Vincent Memorial Research Funds.

\section{References}

Abrahamson JLA, Lee JM and Bernstein A (1995) Regulation of p53-mediated apoptosis and cell cycle arrest by Steel factor. Mol Cell Biol 15: 6953-6960

Alnemri ES. Livingston DJ, Nicholson DW, Salvesen G, Thornberry NA, Wong WW and Yuan J (1996) Human ICE/CED-3 protease nomenclature. Cell 87: 171

Arends MJ, Morris RG and Wyllie AH (1990) Apoptosis. The role of the endonuclease. Am J Pathol 136: 593-608

Baker TG (1963) A quantitative and cytological study of germ cells in human ovaries. Proc Royal Soc London (B) 158: 417-433

Beaumont HM and Mandl AM (1961) A quantitative and cytological study of oogonia and oocytes in the foetal and neonatal rat. Proc Royal Soc London (B) 155:557579

Besmer P, Manova K, Duttlinger R, Huang EJ, Packer A, Gyssler C and Bacharova RF (1993) The kit-ligand (steel factor) and its receptor c-kit/W: pleiotropic roles in gametogenesis and melanogenesis. Development (Supplement) 125-137

Boise LH, Gonzalez-Garcia M, Postema CE, Ding L, Lindsten T, Turka LA, Mao X, Nuñez $G$ and Thompson CB (1993) bcl-x, a bcl-2-related gene that functions as a dominant regulator of apoptotic cell death. Cell 4: 597-608

Borum K (1961) Oogenesis in the mouse: a study of the meiotic prophase. Exp Cell Res 24: 495-507

Braw RH, Bar-Ami S and Tsafriri A (1981) Effect of hypophysectomy on atresia of rat preovulatory follicles. Biol Reprod 25: $989-996$

Byskov, AGS (1974) Cell kinetic studies of follicular atresia in the mouse ovary. J Reprod Fertil 37: 277-285

Cheng EH-Y, Levine B, Boise LH, Thompson CB and Hardwick JM (1996) Baxindependent inhibition of apoptosis by Bcl- $\mathrm{x}_{\mathrm{L}}$. Nature 379: 554-556

Chinnaiyan AM, Orth K, O'Rourke K, Duan H, Poirier GG and Dixit VM (1996) Molecular ordering of the cell death pathway. $\mathrm{Bcl}-2$ and $\mathrm{Bcl}-\mathrm{x}_{\mathrm{L}}$ function upstream of the CED-3-like apoptotic proteases. J Biol Chem 271: 4573-4584

Chun S-Y, Billig H, Tilly JL, Furuta I, Tsafriri A and Hsueh AJW (1994) Gonadotropin suppression of apoptosis in cultured preovulatory follicles: mediatory role of endogenous insulin-like growth factor-I. Endocrinology 135: 1845-1853

Coucouvanis EC, Sherwood SW, Carswell-Crumpton C, Spack EG and Jones PP (1993) Evidence that the mechanism of prenatal germ cell death in the mouse is apoptosis. Exp Cell Res 209: 238-247

Dolci S, Williams DE, Ernst MK, ResnickJL, Brannan CI, LockLF, Lyman SD, Boswell S and Donovan PJ (1991) Requirement for mast cell growth factor for primordial germ cell survival in culture. Nature 352: $809-811$

Estoppey S, Rodriquez I, Sadoul R and Martinou J-C (1997) Bcl-2 prevents activation of CPP32 cysteine protease and cleavage of poly (ADP-ribose) polymerase and U1-70 kD proteins in staurosporine-mediated apoptosis. Cell Death and Differentiation 4: $34-38$

Fernandes-Alnemri T, Litwack G and Alnemri ES (1994) CPP32, a novel human protein with homology to Caenorhabditis elegans cell death protein Ced-3 and mammalian interleukin-1 $\beta$-converting enzyme. J Biol Chem 269: 30761-30764

Flaws JA, DeSanti A, Tilly KI, Javid RO, Kugu K, Johnson AL, Hirshfield AN and Tilly $\mathrm{JL}$ (1995a) Vasoactive intestinal peptide-mediated suppression of apoptosis in the ovary: potential mechanisms of action and evidence of a conserved antiatretogenic role through evolution. Endocrinology 136: 4351-4359

Flaws JA, Kugu K, Trbovich AM, Tilly KI, DeSanti A, Hirshfield AN and Tilly JL (1995b) Interleukin-1 $\beta$-converting enzyme-related proteases (IRPs) and mammalian cell death: dissociation of IRP-induced oligonucleosomal endonuclease activity from morphological apoptosis in granulosa cells of the ovarian follicle. Endocrinology 136: $5042-5053$

Flemming W (1885) Über die bildung von richtungsfiguren in säugethiereiern beim untergang Graaf'scher follikel. Archiv fur Anatomie und Entwickelungsgeschichte (Archives fur Anatomie und Physiologie) 221-244

Forabosco A, Sforza C, De Pol A, Vizzotto L, Marzona L and Ferrario VF (1991) Morphometric study of the human neonatal ovary. Anatom Rec 231: 201-208 Fraser A and Evan G (1996) A license to kill. Cell 85: 781 - 784

Ginther OJ, Wiltbank MC, Fricke PM, Gibbons JR and Kot K (1996) Selection of the dominant follicle in cattle. Biol Reprod 55: 1187-1194 
Godin I, Deed R, Cooke J, Zsebo K, Dexter Mand Wyllie CC (1991) Effects of the steel gene product on mouse primordial germ cells in culture. Nature 352: 807-809

Gottschalk AR, Boise LH, Oltvai ZN, Accavitti MA, Korsmeyer SJ, Quintáns J and Thompson CB (1996) The ability of $\mathrm{Bcl}-\mathrm{X}_{\mathrm{L}}$ and $\mathrm{Bcl}-2$ to prevent apoptosis can be differentially regulated. Cell Death and Differ 3: 113-118

Guthrie HD, Grimes, RW, Cooper BS and Hammond JM (1995) Follicular atresia in pigs: measurement and physiology. J Animal Sci 73: 2834-2844

Hengartner MO and Horvitz HR (1994) Programmed cell death in Caenorhabditis elegans. Curr Opin Genet Develop 4: $581-586$

Hirshfield AN and Midgley Jr AR (1978a) Morphometric analysis of follicular development in the rat. Biol Reprod 19: 606-611

Hirshfield AN and Midgley Jr AR (1978b) The role of FSH in the selection of large ovarian follicles in the rat. Biol Reprod 19: 606-611

Hodgen GD (1982) The dominant ovarian follicle. Fertil Steril 38: 281-300

Hockenberry DM, Oltvai ZN, Yin X-M, Milliman CL and Korsmeyer SJ (1993) Bcl-2 functions in an antioxidant pathway to prevent apoptosis. Cell 75: 241-251

Hughes Jr FM and Gorospe WC (1991) Biochemical identification of apoptosis (programmed cell death) in granulosa cells: evidence for a potential mechanism underlying follicular atresia. Endocrinology 129: 2415-2422

Johnson AL, Bridgham JT, Witty JP and Tilly JL (1996) Susceptibility of avian ovarian granulosa cells to apoptosis is dependent upon stage of follicle development and is related to endogenous levels of $b c l-x_{\text {long }}$ gene expression. Endocrinology 137 : 2059-2066

Kane DJ, Sarafian TA, Anton R, Hahn H, Gralla EB, Valentine JS, Ord T and Bredesen DE (1993) Bcl-2 inhibition of neural death: decreased generation of reactive oxygen species. Science 262: 1274-1277

Keren-Tal I, Suh B-S, Dantes A. Lindner S, Oren M and Amsterdam A (1995) Involvement of p53 expression in CAMP-mediated apoptosis in immortalized granulosa cells. Exp Cell Res 218: 283-295

Kerr JFR, Wyllie AH and Currie AR (1972) Apoptosis: A basic biological phenomenon with wide-ranging implications in tissue kinetics. Br J Cancer 26: 239-257

Knudson CM, Tung KSK, TourtellotteWG, Brown GAJ and Korsmeyer SJ (1995) Baxdeficient mice with lymphoid hyperplasia and male germ cell death. Science 270: 96-99

Knudson CM, Tung KSK, Flaws JA, Brown GAJ, Tilly JL and Korsmeyer SJ (1996) Oocyte survival but spermatocyte cell death in BAX-deficient mice. Proceedings from the International Symposium on Cell Death in Reproductive Physiology, Chicago, IL, p 33

Korsmeyer SJ (1995) Regulators of cell death. Trends in Genetics 11: 101-105

Kumar S (1997) The Bcl-2 family of proteins and activation of the ICE-CED-3 family of proteases: a balancing act in apoptosis? Cell Death and Differ $4: 2-3$

Luciano AM, Pappalardo A., Ray C and Peluso JJ (1994) Epidermal growth factor inhibits large granulosa cell apoptosis by stimulating progesterone synthesis and regulating the distribution of intracellular free calcium. Biol Reprod 51:646-654

Maravei DV, Trbovich AM, Perez GI, Tilly KI, Wong W and Tilly JL (1996) Recombinant CPP32 catalyzes proteolytic degradation of the cytoskeletal elements, $\alpha$-fodrin and $\alpha$-actin. Mol Biol Cell (Supplement) 7: 195a

Martimbeau S, Manganaro TK, Donahoe PK and Tilly JL (1996) Preliminary characterization of an in vitro model to elucidate the regulation of germ cell apoptosis in the intact fetal rat ovary. J Soc Gynecol Invest (Supplement) 3:216A

Martin SJ and Green DR (1995) Protease activation during apoptosis: death by a thousand cuts? Cell 82: 349-352

Mattison DR (1980) Morphology of oocyte and follicle destruction by polycyclic aromatic hydrocarbons in mice. Toxicol Appl Pharmacol 53: 249-259

Mintz B and Russell ES (1957) Gene-induced embryological modifications of primordial germ cells in the mouse. J Exp Zool 134: 207-230

Miyashita T and Reed JC (1995) Tumor suppressor p53 is a direct transcriptional activator of the human bax gene. Cell 80: 293-299

Miyashita T, Harigai M, Hanada M and Reed JC (1994a) Identification of a p53dependent negative response element in the bcl-2 gene. Cancer Res 54:31313135

Miyashita T, Krajewski S, Krajewski M, Wang HG, Lin HK, Liebermann DA, Hoffman B and Reed JC (1994b) Tumor suppressor p53 is a regulator of bcl-2 and bax gene expression in vitro and in vivo. Oncogene 9: 1799-1805

Motro B, van der Kooy D, Rossant J, Reith A and Bernstein A (1991) Contiguous patterns of $c$-kit and steelexpression: analysis of mutations at the Wand S/loci. Development 110: 1057-1069

Oltvai ZN and Korsmeyer SJ (1994) Checkpoints of dueling dimers foil death wishes. Cell 79: 189-192
Oltvai ZN, Milliman CL and Korsmeyer SJ (1993) Bcl-2 heterodimerizes in vivo with a conserved homolog, Bax, that accelerates programmed cell death. Cell 74: $609-619$

O'Shea JD, Hay MF and Cran DG (1978) Ultrastuctural changes in the theca interna during follicular atresia in sheep. J Reprod Fertil 54: 183-187

Patel T, Gores GJ and Kaufmann SH (1996) The role of proteases during apoptosis. FASEB J 10: 587-597

Perry DK, Smyth MJ, Wang H-G, Reed JC, Poirier GG, Obeid LM and Hannun YA (1997) Bcl-2 acts upstream of the PARP proteases and prevents its activation. Cell Death and Differ 4: 29-33

Pesce M and De Felici M (1994) Apoptosis in mouse primordial germ cells: a study by transmission and scanning electron microscope. Anat Embryol 189: 435-440

Pesce M,Farrace MG, Piacentini M, DolciSandDeFeliciM(1993)Stemcell factorand leukemia inhibitory factor promote primordial germ cell survival by suppressing programmed cell death (apoptosis). Development 118: 1089-1094

Pinkerton JHM, McKay DG, Adams EC and Hertig TA (1961) Development of the human ovary: a study using histochemical techniques. Obstet Gynecol 18: 152 181

Quatacker JR (1971) Formation of autophagic vacuoles during human corpus luteum involution. Zeitschrift fur Zellforschung und Mikroskopische Anatomie 122 $479-487$.

Ratts VS, Flaws JA, Kolp R, Sorenson CM and Tilly JL (1995) Ablation of bcl-2 gene expression decreasesthenumbers of oocytes and primordial folliclesestablished in the post-natal female mouse gonad. Endocrinology 136: 3665-3668

ReedJC(1994)Bcl-2and the regulation of programmed cell death.JCellBiol 124:1-6 Rodger FE, Fraser HM, Duncan WC and Illingworth PJ (1995) Immunolocalization of $\mathrm{Bcl}-2$ in the human corpus luteum. Human Reprod 10: 1566-1570

Rueda BR, Tilly KI, Botros I, Jolly PD, Hansen TR, Hoyer PB and Tilly JL (1997) Increased bax and interleukin-1 $\beta$-converting enzyme (Ice) messenger RNA levels coincide with apoptosis in the bovine corpus luteum during structural regression. Biol Reprod 56: 186-193

Sato T, Hanada M, Bodrug S, Irie S, Iwama N, Boise LH, Thompson CB, Golemis E Fong L, Wang H-G and Reed JC (1994) Interactions among members of the Bcl-2 protein family analyzed with a yeast two-hybrid system. Proc Natl Acad Sci USA 91: $9238-9242$

Schwartzman RA and Cidlowski JA (1993) Apoptosis: the biochemistry and molecular biology of programmed cell death. Endocrine Rev 14: 133-151

Sedlak TW, Oltvai ZN, Yang E, Wang K, Boise LH, Thompson CB and Korsmeyer SJ (1995) Multiple Bcl-2 family members demonstrate selective dimerizations with Bax. Proc Natl Acad Sci USA 92: 7834-7838

Springer LN, McAsey ME, Flaws JA, Tilly JL, Sipes IG and Hoyer PB (1996a) Involvement of apoptosis in 4-vinylcyclohexene diepoxide-induced ovotoxicity in rats. Toxicol Appl Pharmacol 139: 394-401

Springer LN, Tilly JL, Sipes IG and Hoyer PB (1996b) Enhanced expression of bax in small preantral follicles during 4-vinylcyclohexene diepoxide-induced ovotoxicity in the rat. Toxicol Appl Pharmacol 139: 402-410

Steinman HM (1995) The Bcl-2 oncoprotein functions as a pro-oxidant. J Biol Chem 270: $3487-3490$

Tilly JL (1994) Use of the terminal transferase DNA labeling reaction for the biochemical and in situ analysis of apoptosis. In Cell biology: a laboratory handbook, in Celis JE, ed. (San Diego: Academic Press) pp. 330-337

Tilly JL (1996) Apoptosis and ovarian function. Rev Reprod 1: 162-172

Tilly JL and Ratts VS (1996) Biological and clinical importance of ovarian cell death Contemp Obstet Gynecol 41: 59-86

Tilly JL and Tilly KI (1995) Inhibitors of oxidative stress mimic the ability of folliclestimulating hormone to suppress apoptosis in cultured rat ovarian follicles. Endocrinology 136: 242-252

Tilly JL, Kowalski KI, Johnson AL and Hsueh AJW (1991) Involvement of apoptosis in ovarian follicular atresia and postovulatory regression. Endocrinology 129: $2799-2801$

Tilly JL, Billig H, Kowalski KI and Hsueh AJW (1992) Epidermal growth factor and basic fibroblast growth factor suppress the spontaneous onset of apoptosis in cultured rat ovarian granulosa cells and follicles by a tyrosine kinase-dependent mechanism. Mol Endocrinol 6: 1942-1950

Tilly JL, Tilly KI, Kenton ML and Johnson AL (1995a) Expression of members of the $b c l-2$ gene family in the immature rat ovary: equine chorionic gonadotropinmediated inhibition of apoptosis is associated with decreased bax and constitutive $b c l-2$ and $b c l-2_{\text {long }}$ messenger ribonucleic acid levels. Endocrinology 136: $232-241$ 
Tilly JL, Flaws JA, DeSanti A, Kugu K, Rubin JS and Hirshfield AN (1995b) Role of intrafollicular growth factors in maturation and atresia of rat ovarian follicles. Biol Reprod (Supplement 1) 52: 159

Tilly KI, Banerjee S, Banerjee PP and Tilly JL (1995c) Expression of the p53 and Wilms' tumor suppressor genes in the rat ovary: gonadotropin repression in vivo and immunohistochemical localization of nuclear p53 protein to apoptotic granulosa cells of atretic follicles. Endocrinology 136: 1394-1402

Tilly JL, Kugu K, Ratts VS, Piquette GN, Tilly KI, Aberdeen GW, Pepe J and Albrecht ED (1996a) Apoptosis and cell death gene expression in the human and baboon ovary. J Soc Gynecol Invest (Supplement) 3: 70A

Tilly JL, Tao XJ and Ratts VS (1996b) Immunolocalization of the BAX deathsusceptibility factor in the regressing human corpus luteum. Proceedings from the 52nd Annual Meeting of the American Society for Reproductive Medicine, Boston, MA, p S136

Trbovich AM, Hughes Jr FM, Perez GI, Tilly KI, Cidlowski JA and Tilly JL (1996a) Requirement for ICE-related protease (IRP) activity in oligonucleosomal endonuclease activation during apoptosis resides in the cytoplasmic compartment of rat ovarian granulosa cells. Proceedings from the International Symposium on Cell Death in Reproductive Physiology, Chicago, IL, p 36

Trbovich AM, Hughes Jr FM, Perez GI, Kugu K, Flaws JA, DeSanti AM, Hirshfield AN and Tilly JL (1996b) High molecular weight DNA cleavage occurs in apoptotic granulosa cells (GC) of atretic follicles and is induced via a pathway independent of interleukin-1 $\beta$-converting enzyme (ICE) activity. J Soc Gynecol Invest (Supplement) 3: 173A
Wang L, Miura M, Bergeron L, Zhu H and Yuan J (1994) Ich-1, an ICE/ced-3-related gene, encodes both positive and negative regulators of programmed cell death. Cell 78: $739-750$

Williams JR, Little JB and Shipley WU (1974) Association of mammalian cell death with specific endonucleolytic degradation of DNA. Nature 252: 754-756

Wyllie AH (1980) Glucocorticoid-induced thymocyte apoptosis is associated with endogenous endonuclease activation. Nature 284: 555-556

Yin X-M, Oltvai ZN and Korsmeyer SJ (1994) BH1 and BH2 domains of Bcl-2 are required for inhibition of apoptosis and heterodimerization with Bax. Nature 369 $321-323$

Zeleznik AJ (1981) Premature elevation of systemic estradiol reduces serum level of follicle-stimulating hormone and lengthens the follicular phase of the menstrual cycle in rhesus monkeys. Endocrinology 109: 352-355

Zeleznik AJ, Schuler HM and Reichert Jr LE (1981) Gonadotropin binding sites in the rhesus monkey ovary: role of the vasculature in the selective distribution of human chorionic gonadotropin to the preovulatory follicle. Endocrinology 109: $356-362$

Zeleznik AJ, Hutchinson JS and Schuler HM (1985) Interference with the gonadotropin-suppressing actions of estradiol in macaques overrides the selection of a single preovulatory follicle. Endocrinology 117: 991 -999

Zeleznik AJ, Ihrig L and Bassett SG (1989) Developmental expression of a $\mathrm{Ca}^{++}$ $\mathrm{Mg}^{++}$-dependent endonuclease activity in rat granulosa and luteal cells. Endocrinology 125: 2218-2220 